\title{
Clinical validation of fall prevention behavior in a hospital environment
}

\author{
Validação clínica do comportamento de prevenção de quedas em ambiente hospitalar \\ Validación clínica del comportamiento de prevención de caídas en ambiente hospitalario
}

\section{Jéssica Naiara de Medeiros Araújo', Ana Paula Nunes de Lima Fernandes', Amanda Barbosa da Silva', Laísla Alves Moura', Marcos Antonio Ferreira Júnior", Allyne Fortes Vitor' \\ ' Universidade Federal do Rio Grande do Norte. Natal, Rio Grande do Norte, Brazil. \\ "Universidade Federal do Mato Grosso do Sul. Campo Grande, Mato Grosso do Sul, Brazil.}

How to cite this article:

Araújo JNM, Fernandes APNL, Silva AB, Moura LA, Ferreira Jr MA, Vitor AF. Clinical validation of fall prevention behavior in a hospital environment. Rev Bras Enferm [Internet]. 2018;71(4):1841-9. DOI: http://dx.doi.org/10.1590/0034-7167-2017-0212

Submission: 03-30-2017

Approval: 07-09-2017

\begin{abstract}
Objective: Clinically validate the Nursing Outcome Behavior of falls prevention in hospitalized patients. Method: This was a cross-sectional study developed at a public university hospital with a sample of 45 patients. The data collection was performed through the evaluation of four nurses, with a double used the instrument with the constitutive and operational definitions of the indicators and magnitudes of the Fall Prevention Behavior Result, while the other pair did not use such definitions. Results: When applying the non-parametric analysis of variance by the Friedman test, ten indicators showed statistical differences between the inferences made by the evaluators for each patient. In relation to the intraclass correlation coefficient, confidence interval and $p$ value assigned to each indicator of the scale, most of the indicators were statistically significant. Conclusions: The instrument referring to the Fall Behavior Outcome Behavior was considered valid for the study population.
\end{abstract}

Descriptors: Validation Studies; Evaluation of Results (Health Care); Accidents by Fall; Nursing Processes; Nursing.

\section{RESUMO}

Objetivo: Validar clinicamente o Resultado de Enfermagem Comportamento de prevenção de quedas em pacientes internados em ambiente hospitalar. Método: Trata-se de um estudo transversal desenvolvido em um hospital universitário público, com uma amostra de 45 pacientes. A coleta de dados ocorreu mediante avaliação de quatro enfermeiros, sendo que uma dupla utilizou o instrumento com as definições constitutivas e operacionais dos indicadores e magnitudes do Resultado Comportamento de prevenção de quedas, enquanto a outra dupla não utilizou tais definições. Resultados: Ao aplicar a análise de variância não paramétrica pelo teste de Friedman, dez indicadores mostraram diferenças estatísticas entre as inferências feitas pelos avaliadores para cada paciente. Em relação ao coeficiente de correlação intraclasse, intervalo de confiança e valor $p$ atribuído a cada indicador da escala, a maioria dos indicadores foi estatisticamente significante. Conclusões: $\mathrm{O}$ instrumento referente ao Resultado Comportamento de prevenção de quedas foi considerado válido para a população estudada.

Descritores: Estudos de Validação; Avaliação de Resultados (Cuidados de Saúde); Acidentes por Queda; Processos de Enfermagem; Enfermagem.

\section{RESUMEN}

Objetivo: Validar clínicamente el Resultado de Enfermería Comportamiento de prevención de caídas en pacientes hospitalizados en ambiente hospitalario. Método: Se trata de un estudio transversal desarrollado en un hospital universitario público, con una muestra de 45 pacientes. La recolección de datos ocurrió mediante evaluación de cuatro enfermeros, dado que un par utilizó el instrumento con las definiciones constitutivas y operativas de los indicadores y magnitudes del Resultado Comportamiento de prevención de caídas, mientas que otro par no utilizó estas definiciones. Resultados: Al aplicar el análisis de varianza no paramétrica por la prueba de Friedman, diez indicadores mostraron diferencias estadísticas entre las inferencias hechas por los evaluadores para cada paciente. En cuanto al coeficiente de correlación intraclase, intervalo de confianza y valor $p$ asignado 
a cada indicador de la escala, la mayoría de los indicadores fue estadísticamente significativa. Conclusiones: El instrumento referente al Resultado Comportamiento de prevención de caídas fue considerado válido para la población estudiada.

Descriptores: Estudios de Validación; Evaluación de Resultados (Cuidados de Salud); Accidentes por Caída; Procesos de Enfermería; Enfermería.

\section{CORRESPONDING AUTHOR Jessica Naiara de Medeiros Araújo E-mail: jessicanaiara_rn@hotmail.com}

\section{INTRODUCTION}

In the hospital clinical scenario, health institutions have offered assistance to patients at an increasing level of criticality, since they demand an increasingly specialized care. This situation requires professionals of excellence who accompany the technological innovations and the epidemiological and demographic transitions of the population ${ }^{(1)}$.

Thus, in relation to nurses, the growing demand for measuring and describing the results of care practice emerges. This reality is made possible by the creation of the Nursing Outcomes Classification (NOC). The NOC is presented as a nursing classification system that is linked to NANDA International, Inc. (NANDA-I) and the Nursing Interventions Classification (NIC). The NOC presents nursing results that are measured by indicators and allow monitoring of the patient's health status ${ }^{(2-3)}$. Through NOC, the nurse promotes the follow-up to the Nursing Process and determines if the expected results for the patient's clinic were reached ${ }^{(4)}$.

At national and international level, the use of the NOC for nursing and validation studies is still considered incipient; however, there is a strong tendency to use this taxonomy. At the international level, there are increasing scientific investigations about validations of nursing results using NOC, however, this quantitative still is scarce in the research. Thus, it is evident the need to carry out these studies to subsidize the nursing care provided to the patient ${ }^{(5)}$.

It is necessary to emphasize that validation studies contribute to the decision making and assistance provided by the nurse in that they use important indicators for the patient's clinic and eliminate those that are not relevant to their health situation ${ }^{(5)}$.

The use of these classification systems in nursing is constantly developing, and for this reason, diagnoses, interventions and results need to be put into practice from validation studies, in order to guarantee greater reliability and accuracy in the practice of nursing. Together with this fact, this use contributes to nurses' autonomy and decision-making regarding health situations ${ }^{(2,6)}$.

The nurse in a hospital environment is faced with several situations that require specialized clinical care. Thus, there is a need to minimize the occurrence of adverse events that compromise the patient's clinical condition. In this sense, one of the important focuses of health institutions is focused on the prevention of such events ${ }^{(7)}$.

Due to the importance given to the issue and the possibility of irreparable damages in some situations, the National Patient Safety Programme (PNSP) was created in 2013 by the Ministry of Health, whose objective is to prevent and minimize adverse events. The PNSP deals with the management of clinical protocols and presents as one of its priorities the reduction of the risk of falls ${ }^{(8)}$.
The fall is defined as an involuntary body movement from the initial position to a lower level. It is a notorious multi-causal adverse event that can lead to situations of vulnerability to the affected individual(7). Complications from the fall range from physical impairment, such as dislocations, excoriations and fractures, to psychological complications that lead, in some situations, to reduced movement and fear of performing activities considered daily ${ }^{(9)}$.

Although the hospital environment has the main function of providing services aimed at the restoration of health and the maintenance of life, it is considered a place conducive to the occurrence of falls. The problem of this study is focused on the high frequency of this adverse event in this context, which is due to intrinsic factors (senescence, physiological changes caused by diseases, muscular weakness, problems with balance, gait or stability, multiple drug therapy and postural hypotension) and extrinsic (lack of support equipment, poor distribution of furniture, poor lighting, improper use of railings, irregular or poor floors, presence of noise and lack of communication or exchange of information among health professionals) $)^{(7)}$.

In this context, the NOC can act as a risk management tool for falls, especially the Nursing Outcome Fall prevention behavior, defined as personal actions or the family caregiver to minimize risk factors capable of precipitating falls in the personal environment, and inserted in the Knowledge of Health and Behavior domain and in the Risk Control and Safety class ${ }^{(3,10)}$. The validation of results like this in the hospital context is capable of generating evidence that attest to the functionality and risk management of this taxonomic element. Therefore, it is relevant to validate the behavior of falls prevention in a hospital environment, and especially its clinical indicators.

\section{OBJECTIVE}

Clinically validate the Nursing Outcome Behavior of falls prevention in hospitalized patients.

\section{METHOD}

\section{Ethical aspects}

It should be noted that the study complied with the formal requirements of Resolution 466/2012, referring to research with human beings ${ }^{(11)}$, and obtained approval by the Research Ethics Committee of the Universidade Federal do Rio Grande do Norte. All the individuals and nurses who accepted to participate in the research were informed of the methodological procedures and provided their consent by signing the Free and Clear Consent Term (FCCT).

\section{Design, place of study and period}

It is a cross-sectional and descriptive study carried out in a university hospital belonging to the public health network and 
located in the city of Natal / RN. Data were collected from August to September 2013 by four nurses who were previously trained.

\section{Population or sample, inclusion and exclusion criteria}

The population was composed of patients hospitalized in the medical and surgical clinic units of the mentioned hospital. Therefore, to establish the sample size, the following formula was established: $N=(z \alpha+z \beta)^{2}$. 2. $P(1-p) /(d)^{2}$, where $N=$ sample size, $z \alpha=$ confidence level, $z \beta=$ test power, $p=$ proportion of occurrence of the phenomenon under study, $d=$ difference to be detected evaluations when considering operational definitions $\mathrm{s}^{(12)}$.

A $95 \%$ confidence level $(z \alpha=1.96)$ and a test power of $80 \%$ $(\mathrm{z} \beta=0.84)$ were considered in this study. The estimated proportion, measured based on the prevalence of the diagnosis Risk of falls identified in an earlier study, was $86.25 \%(p=0.87)^{(13)}$. The change detection difference when using or not definitions was set at $20 \%(d=0.2)$. Based on the exposed parameters, the sample was calculated in 45 patients who presented the nursing diagnosis Risk of falls. The selection of the subjects for the sample composition was performed by consecutive sampling.

Thus, only patients with a nursing diagnosis of falls, aged 18 years or more and hospitalized in the medical and surgical clinics of the referred hospital, were included in this sample. Patients with discharge prediction for the following 24 hours were excluded, as it was considered that one of the pairs of evaluators could not apply the questionnaire before discharge. Thus, after establishing the Risk of falls diagnosis, the researcher was certified by medical records and the head of the nursing team if there was a possibility of discharge to the patient in the subsequent 24 hours. If so, the patient became ineligible for research.

\section{Study protocol}

The data collection instrument was constructed through prior concept analysis that established the possible operational and constitutive definitions and operational magnitudes of the Nursing Outcome Indicators Fall prevention behavior. These components were submitted to content validation by 16 nurses with a degree/experience in research, teaching or assistance in clinical nursing care and/or in nursing terminology and/ or in accidents due to falls/patient safety, in order to judge the adequacy of the content. The instrument used included variables related to sociodemographic and clinical data and to the evaluation of the indicators of the Nursing Outcome under study (with definitions or without definitions, depending on the pair of evaluators).

A pilot collection with four patients hospitalized in the hospital's medical clinic was performed in advance, since it is essential to adjust the instrument, as well as to verify if the items to be evaluated were really comprehensible to the context of the study. After this test, it was noticed that there was no need for modifications in the instrument.

Thus, four previously trained nurses were selected to perform the peer evaluation of patients with a nursing diagnosis, Risk of falls through the use of two types of instrument (with definitions or without definitions). The following criteria were used for the selection of nurses: to have at least one year of professional experience in the care of hospitalized patients, or to be part of a research group that works on the topic of nursing diagnoses, interventions and results.

After the selection of the nurses, a lottery was made for the composition of the two evaluators. In order to judge the clinical applicability of the conceptual and operational definitions and the operational magnitudes of each indicator, a pair of evaluators had access to the instrument that contained only the Nursing Outcome Fall prevention behavior as found in the NOC edition, title of indicators and Likert scale. The Likert scale ranges from 1 to 5 (never shown, rarely demonstrated, sometimes demonstrated, often demonstrated and consistently demonstrated) ${ }^{(3)}$. In contrast, the other pair completely appropriated the content of the instrument constructed and validated for content. It is important to point out at this point that each nurse evaluator had access only to the content of the instrument he used in the evaluations. It is emphasized that each patient was evaluated by both pairs at different times, within the time period of up to 24 hours after the inference of the diagnosis Risk of falls.

In order to carry out the evaluation, the selected nurses received a 20-hour training in which topics related to the problem of falls in the world and national context were analyzed, to the Nursing Assistance Systematization, to the nursing taxonomies, with emphasis to the NOC, to the explanation of the NOC outcome indicators.

The data collection took place without a fixed scale for the evaluators, who were on the alert for a possible collection, which would be performed depending on the availability of the diagnosed patients. This availability was verified by the researcher through daily visits to the site, from the identification of the risk factors at the bedside and in the chart, to determine the inference of the nursing diagnosis Risk of falls.

\section{Results analysis and statistics}

After the data collection, the information was stored and organized into a Microsoft Excel 2010 spreadsheet and then tabulated using the Statistical Package for Social Sciences software (SPSS 20.0).

For the descriptive analysis, we considered the frequencies, measures of the distribution center and their variabilities. To verify the normality of the data, the Shapiro-Wilk test was used. In order to measure the median difference between the two groups of evaluators, the Friedman test was used. The intraclass correlation coefficient (ICC) was used to compare the correlation between the evaluations performed by the peer reviewers. The objective of this analysis was to verify the degree of relationship between the evaluations performed by the pairs of subjects who used or not the constructed definitions. The evaluation was performed to compare the correlation among the evaluators who used the same evaluation strategy.

\section{RESULTS}

Of the 45 participants, $57.8 \%$ were women with a mean age of 57.87 years $( \pm 13.9)$. The period of hospitalization was about 8 days. In addition, $86.7 \%$ of the participants were in the postoperative period. Table 1 below shows the risk factors for the nursing diagnosis Risk of falls identified in the research participants. 
Table 1 - Risk factors for nursing diagnosis Risk of NANDA-I falls identified in hospitalized patients, Natal, Rio Grande do Norte State, Brazil, 2013

\begin{tabular}{|c|c|c|}
\hline Variables & $\mathbf{n}$ & $\%$ \\
\hline \multicolumn{3}{|l|}{ Environmental risk factors } \\
\hline Environment with furniture and objects in excess & 45 & 100.0 \\
\hline Absence of non-slip material & 45 & 100.0 \\
\hline Absence of non-slip material in shower enclosure & 45 & 100.0 \\
\hline Non-Family Room & 16 & 35.6 \\
\hline Poor lighting & 03 & 6.7 \\
\hline Climate conditions & 02 & 4.4 \\
\hline Immobilization & 02 & 4.4 \\
\hline Rug scattered on the floor & 01 & 2.2 \\
\hline \multicolumn{3}{|l|}{ General risk factors } \\
\hline Age over 65 years & 17 & 37.8 \\
\hline History of falls & 05 & 11.1 \\
\hline \multicolumn{3}{|l|}{ Physiological risk factors } \\
\hline Postoperative Conditions & 39 & 86.7 \\
\hline Visual impairments & 17 & 37.8 \\
\hline Anemias & 15 & 33.3 \\
\hline Foot problem & 09 & 20.0 \\
\hline Lack of sleep & 08 & 17.8 \\
\hline Impaired physical mobility & 07 & 15.6 \\
\hline Difficulty walking & 06 & 13.3 \\
\hline Decreased strength in the lower extremities & 04 & 8.9 \\
\hline Orthostatic hypotension & 03 & 6.7 \\
\hline Auditory difficulties & 03 & 6.7 \\
\hline Impaired balance & 02 & 4.4 \\
\hline Arthritis & 02 & 4.4 \\
\hline Change in post-meal sugar & 01 & 2.2 \\
\hline Vascular disease & 01 & 2.2 \\
\hline \multicolumn{3}{|l|}{ Drug risk factors } \\
\hline ACE Inhibitors & 11 & 24.4 \\
\hline Narcotics / opiates & 11 & 24.4 \\
\hline Diuretics & 10 & 22.2 \\
\hline Alcohol use & 07 & 15.6 \\
\hline Antihypertensives & 06 & 13.3 \\
\hline Anxiolytics & 01 & 2.2 \\
\hline
\end{tabular}

Note: $A C E$ - angiotensin converting enzyme

We identified 30 risk factors related to environmental, general, physiological and drug use factors. In relation to environmental risk factors, the following were highlighted in $100 \%$ of the evaluated patients: the environment with furniture and objects in excess, the absence of anti-slip material and the absence of non-slip material in the shower stall. Of the general risk factors, $37.8 \%$ of the patients were older than 65 years. According to the physiological risk factors, the postoperative conditions were present in $86.7 \%$ of the patients. The most used drugs that contributed as risk factors were angiotensin converting enzyme (ACE) inhibitors and narcotics/opiates, both present in $24.4 \%$ of the sample, and diuretics in $22.2 \%$ of the sample.

Table 2 below shows the comparison between evaluators' evaluations (average of the stations) in relation to the instrument with and without definitions of the indicators.
When applying the non-parametric analysis of variance by the Friedman test, ten indicators showed statistical differences between the inferences made by the evaluators for each patient, namely: It makes use of barriers to prevent falls during the stay in bed, Keeps the environment free of accumulation of objects and obstacles and fluids on the floor, Uses proper footwear to prevent falls, Uses chairs properly, Uses bed properly, Controls agitation and restlessness, Takes precautions when taking medicines that increase the risk of falls, Uses safe actions during transfer , Manages urinary/intestinal urgency and makes use of clothes of appropriate size.

It was not possible to perform the tests for the indicator Uses adequately stool and stairs, since this item obtained predominantly "Not applicable" answers. In addition, it is emphasized that the differences between the evaluations of the two pairs, in some situations, refer only to one of the examiners.

Table 3 shows the intraclass correlation coefficient, confidence interval and $p$ value assigned for each scale indicator.

At a significance level of $5 \%$, most of the indicators were statistically significant, especially for the evaluations with the instrument that contained the definitions. However, some indicators presented confidence intervals with negative values, which show incongruence among the evaluators. In addition, it was not possible to calculate ICC, confidence interval and Friedman test for some indicators, due to the low number of responses.

In relation to the evaluators who used the instrument with the definitions, the indicators Properly uses auxiliary mechanisms to wander, Keeps the environment free of accumulation of objects and obstacles and liquids on the floor, Uses appropriate footwear to prevent falls, Adapts the height of the toilet according to the need, Uses chairs appropriately, Uses properly the bed, Uses rubber mats in the bathtub or shower box, Controls agitation and restlessness and Uses safe actions during transfer have low intraclass correlation coefficient $(<0.4)$. This result may indicate low reliability for evaluation of these items, making it necessary to modify and clarify the proposed definitions. In the remaining cases, the coefficient was excellent (ICC $\geq 75$ ) or satisfactory $(0,4 \leq$ ICC $<0.75)$.

For the evaluators who used the instrument without the definitions, the indicators Uses adequate footwear to prevent falls, Uses rubber mats in the bathtub or shower box, Takes precautions when taking medicines that increase the risk of falls and Manages urinary/intestinal urgency presented low intraclass correlation coefficient (ICC <0.4). In the remaining cases, the coefficient was excellent (ICC $\geq 75$ ) or satisfactory $(0.4 \leq$ ICC $<0.75)$. 
Table 2 - Comparison between evaluators' evaluations (average of stations) in relation to the instrument with and without definitions of the indicators, Natal, Rio Grande do Norte State, Brazil, 2013

\begin{tabular}{|c|c|c|c|c|c|}
\hline \multirow[t]{2}{*}{ Indicator } & \multicolumn{2}{|c|}{$\begin{array}{l}\text { With definitions } \\
\text { Evaluator }\end{array}$} & \multicolumn{2}{|c|}{$\begin{array}{l}\text { Without definitions } \\
\text { Evaluator }\end{array}$} & \multirow{2}{*}{$\underset{\text { value* }}{p}$} \\
\hline & 1 & 2 & 1 & 2 & \\
\hline Properly uses auxiliary mechanisms to wander & 3.00 & 2.50 & 2.75 & 1.75 & 0.776 \\
\hline Asks for physical assistance for yourself & 2.29 & 2.49 & 2.68 & 2.55 & 0.293 \\
\hline Uses barriers to prevent falls during bedtime & 2.26 & 2.44 & 2.96 & 2.34 & 0.007 \\
\hline Uses handrails as needed & 2.82 & 2.50 & 2.47 & 2.21 & 0.173 \\
\hline Keeps the environment free from accumulation of objects and obstacles and liquids on the floor & 2.31 & 2.89 & 2.70 & 2.10 & 0.005 \\
\hline Properly uses stool and stairs & -- & -- & -- & -- & -- \\
\hline Uses adequate footwear to prevent falls & 2.54 & 3.74 & 1.42 & 2.31 & $<0.001$ \\
\hline Adapts the height of the toilet according to need & 2.29 & 2.36 & 2.77 & 2.58 & 0.203 \\
\hline Uses chairs appropriately & 1.66 & 2.51 & 3.19 & 2.64 & $<0.001$ \\
\hline Uses bed properly & 2.40 & 2.18 & 2.97 & 2.45 & 0.014 \\
\hline Uses rubber mats in the bathtub or shower box & 2.64 & 2.45 & 2.45 & 2.45 & 0.112 \\
\hline Uses safety bars in the bathroom for hand support & 2.44 & 2.49 & 2.67 & 2.40 & 0.630 \\
\hline Controls agitation and restlessness & 1.87 & 3.08 & 2.44 & 2.61 & $<0.001$ \\
\hline Takes precautions when taking medicines that increase the risk of falls & 2.83 & 3.03 & 2.37 & 1.77 & 0.021 \\
\hline Appropriately uses vision correction features & 2.65 & 2.38 & 2.48 & 2.48 & 0.771 \\
\hline Uses safe actions during transfer & 1.91 & 2.09 & 3.17 & 2.83 & $<0.001$ \\
\hline Correctly uses the alarm system & 2.50 & 2.45 & 2.67 & 2.37 & 0.460 \\
\hline Manage urinary/intestinal urgency & 2.63 & 2.75 & 2.92 & 1.71 & $<0.001$ \\
\hline Wears appropriately sized clothes & 1.88 & 2.85 & 2.64 & 2.63 & $<0.001$ \\
\hline Correctly uses auditory correction features & 3.50 & 3.00 & 1.75 & 1.75 & 0.284 \\
\hline
\end{tabular}

Note: *Friedman Test.

Table 3 - Presentation of the intraclass correlation coefficient, confidence interval and $p$ value assigned for each scale indicator, Natal, Rio Grande do Norte State, Brazil, 2013

\begin{tabular}{|c|c|c|c|c|c|c|c|c|}
\hline \multirow{2}{*}{ Indicator } & \multicolumn{4}{|c|}{$\begin{array}{l}\text { Instrument Evaluators } \\
\text { with definitions }\end{array}$} & \multicolumn{4}{|c|}{$\begin{array}{l}\text { Instrument Evaluators } \\
\text { without definitions }\end{array}$} \\
\hline & $\mathbf{n}$ & $\mathrm{ICC}^{1}$ & $\mathbf{C l}$ & $\begin{array}{l}\text { Value } \\
\text { of } p^{*}\end{array}$ & $\mathbf{n}$ & $\mathrm{ICC}^{1}$ & $\mathrm{Cl}$ & $\underset{\text { value* }}{p}$ \\
\hline Properly uses auxiliary mechanisms to wander & 45 & 0.24 & $-0.38 ; 0.58$ & 0.181 & 2 & - & - & - \\
\hline Asks for physical assistance for you & 45 & 0.82 & $0.67 ; 0.90$ & $<0.001$ & 42 & 0.83 & $0.68 ; 0.91$ & $<0.001$ \\
\hline Use of barriers to prevent falls during bedtime & 45 & 0.79 & $0.62 ; 0.89$ & $<0.001$ & 45 & 0.77 & $0.57 ; 0.87$ & $<0.001$ \\
\hline Uses handrails as needed & 45 & 0.71 & $0.48 ; 0.84$ & $<0.001$ & 31 & 0.77 & $0.52 ; 0.89$ & $<0.001$ \\
\hline $\begin{array}{l}\text { Keeps the environment free from accumulation of objects and obstacles } \\
\text { and liquids on the floor }\end{array}$ & 45 & -1.46 & $-3.47 ;-0.35$ & 0.998 & 44 & 0.80 & $0.63 ; 0.89$ & $<0.001$ \\
\hline Properly uses stool and stairs & 9 & - & - & - & 17 & 0.67 & $0.09 ; 0.88$ & 0.017 \\
\hline Uses adequate footwear to prevent falls & 44 & -0.38 & $-1.52 ; 0.25$ & 0.851 & 43 & -0.46 & $-1.70 ; 0.21$ & 0.889 \\
\hline Adapts the height of the toilet according to need & 45 & 0.19 & $-0.48 ; 0.55$ & 0.248 & 42 & 0.70 & $0.44 ; 0.84$ & $<0.001$ \\
\hline Uses chairs appropriately & 45 & 0.42 & $-0.06 ; 0.68$ & 0.039 & 40 & 0.72 & $0.46 ; 0.85$ & $<0.001$ \\
\hline Uses bed properly & 45 & 0.16 & $-0.52 ; 0.54$ & 0.282 & 44 & 0.63 & $0.33 ; 0.80$ & 0.001 \\
\hline Uses rubber mats in the bathtub or shower box & 45 & -0.06 & $-0.93 ; 0.42$ & 0.575 & 43 & -0.02 & $-0.88 ; 0.45$ & 0.529 \\
\hline Uses safety bars in the bathroom for hand support & 45 & 0.75 & $0.55 ; 0.86$ & $<0.001$ & 43 & 0.92 & $0.85 ; 0.96$ & $<0.001$ \\
\hline Controls agitation and restlessness & 45 & 0.33 & $-0.22 ; 0.63$ & 0.096 & 45 & 0.95 & $0.91 ; 0.97$ & $<0.001$ \\
\hline Takes precautions when taking medicines that increase the risk of falls & 45 & 0.84 & $0.70 ; 0.91$ & $<0.001$ & 15 & 0.20 & $-1.37 ; 0.73$ & 0.339 \\
\hline Appropriately uses vision correction features & 45 & 0.71 & $0.47 ; 0.84$ & $<0.001$ & 13 & 0.73 & $0.45 ; 0.87$ & $<0.001$ \\
\hline Uses safe actions during transfer & 45 & -0.39 & $-1.54 ; 0.23$ & 0.863 & 44 & 0.75 & $0.55 ; 0.86$ & $<0.001$ \\
\hline Correct use of the alarm system & 45 & 0.92 & $0.86 ; 0.96$ & $<0.001$ & 43 & 0.72 & $0.48 ; 0.85$ & $<0.001$ \\
\hline Manages urinary/intestinal urgency & 45 & 0.73 & $0.50 ; 0.85$ & $<0.001$ & 36 & -1.06 & $-3.04 ;-0.05$ & 0.982 \\
\hline Wears appropriately sized clothes & 45 & 0.77 & $0.58 ; 0.87$ & $<0.001$ & 43 & 0.89 & $0.79 ; 0.94$ & $<0.001$ \\
\hline Correctly uses auditory correction features & 45 & 0.76 & $0.57 ; 0.87$ & $<0.001$ & 2 & - & - & - \\
\hline
\end{tabular}

Note: * Friedman Test; ICC - Intraclass Correlation Coefficient; CI - Confidence Interval. 


\section{DISCUSSION}

The results presented here show the importance of scientific productions focusing on clinical validations of nursing results, since these are poorly developed studies ${ }^{(4)}$, especially regarding the approach to prevent falls in hospital settings.

When analyzing the sociodemographic characterization of the patients in the study, it was observed a similarity to previous investigations carried out in different regions of the country, in which women predominated for falls occurring in a hospital environment ${ }^{(14-15)}$. Linked to this, another recent study pointed to women as a high risk group for falls ${ }^{(16)}$.

However, the mean age of participants (57.87 years) was different from other productions on the subject, which showed a higher percentage of elderly people ${ }^{(14-15)}$. The elderly, especially women, are at high risk of falls due to their greater fragility, the frequency of chronic diseases, the common use of medications and the increase in the life expectancy of women in relation to $\operatorname{men}^{(17)}$.

Regarding the environmental risk factors that were highlighted in $100 \%$ of the patients, it is worth mentioning that the individual's change from the home environment to the hospital entails physical, social and environmental adaptation. In this sense, it is necessary that the aggravating factors of the risk of falls be minimized in order to provide a safe and organized environment. In addition, it is important to highlight that all the environmental risk factors presented in the present study were related to the room/ward and bathroom. This information corroborates other studies that point out these two sites as the most frequent ones for occurrence of falls $s^{(18-19)}$.

The fact that most individuals are in the postoperative period may have contributed to the occurrence of falls. This is because, at the moment after the surgical procedure, the patient is in a situation of vulnerability, either by the return of anesthetic induction, by the type of surgery performed or by the use of various hospital devices that may compromise ambulation. Thus, such patients demand care and special attention from the nursing team ${ }^{(13)}$.

In addition, the use of some medications may contribute to the occurrence of falls, as demonstrated. In this sense, another study reports that angiotensin-converting enzyme inhibitors and diuretics are among the drugs used to increase the risk of falls due to their adverse effects, such as cramps, muscle weakness, dizziness and orthostatic hypotension, which may lead to impairment of gait and balance ${ }^{(20)}$.

Narcotics/opiates are related to falls because of their potential central nervous system depression ${ }^{(21)}$. Thus, it is fundamental that nurses understand and evaluate the effects of medications used by patients, in order to guide their administration, interactions, contraindications and adverse effects ${ }^{(20)}$.

Regarding the indicators of Nursing Outcome under study, it is important to note the importance of the prevention of falls in daily life of hospitalized patients, in order to measure adherence to prevention strategies and to identify how it occurs from correct and validated professional orientations. Thus, it is understood the importance of using this taxonomy in order to promote the prevention of falls ${ }^{(22)}$.
Regarding the analysis of the evaluation among the nurses' evaluators, there were no statistically significant differences between the indicators: Properly uses auxiliary mechanisms to wander, Request physical assistance for himself, Use handrails as needed, Adapt the height of the toilet according to the need, Uses rubber bars in the bathtub or shower box, Uses, in the bathroom, safety bars for hand support, Properly utilizes vision correction features, Correct use of alarm system and Correctly uses auditory correction features. This finding may be related to the ease and frequency of evaluation of these indicators in different clinical contexts. However, they are considered important for the evaluation of hospitalized patients. A similar result for some indicators was identified in a study performed in patients with stroke ${ }^{(22)}$.

Regarding the other indicators, statistical differences were observed when comparing the evaluations of the nurses who used the instrument with and without the definitions. These differences may be the result of the described definitions and the parameters developed for each magnitude of the indicator, which promotes greater ease of discernment to define the cut-off point assigned for differentiation between each one, with cutoff points ranging between never demonstrated to consistently demonstrated ${ }^{(4,23)}$

Coupled with this, the greater frequency of statistical differences in the pair with definitions may be related to the fact that the NOC indicators of the Fall Prevention Behavior are sufficient to respond to the patient's need in the applied clinical context. However, when more indicators were found to be insufficient for the evaluators who used the instrument with the definitions, the possibility arises that the definitions constructed by the study are not adequate for the scenario, which establishes the need for possible change or clarification of the proposed definitions. Thus, it is pointed out the need to revise some indicators, in order to establish their applicability or not ${ }^{(4)}$.

In addition, when considering that the pair of nurses who did not use the instrument with the definitions showed a better performance for some indicators, it is questioned if there was any misunderstanding of the definitions made or if there is a real need for the adequacy and applicability of these definitions in clinical practice in the specific scenario of the study, with the possibility of some indicators being intelligible only with the labels presented in the $\mathrm{NOC}^{(4)}$.

Regarding the indicator Adequately use stools and stairs, it is believed that the impossibility of carrying out the statistical tests was due to a characteristic of the environment itself, since in some wards no stools and stairs were used, or also due to inadequate understanding of the indicator, which led the nurse evaluators to opt for the "Not applicable" answer in most cases.

Regarding the other analyzes, it was not possible, for the evaluators who used the instrument without definitions, to calculate ICC, confidence interval and Friedman test for the indicators. Properly uses auxiliary mechanisms to wander and Correctly uses auditory correction resources. This impossibility may also have occurred due to inadequate understanding of the indicators, due to the lack of constitutive, operational and magnitude definitions. Thus, as discussed, the answer "Not applicable" was used in greater quantity. 
By observing in a general way the use of the indicators with the constitutive and operational definitions, it was possible to verify that there was concordance among the evaluators for a significant number of indicators, even with the lack of uniformity in some cited previously. Thus, the constitutive, operational definitions and magnitudes constructed favored a greater standardization of the evaluations performed among nurses, in agreement with other validation studies in different clinical settings ${ }^{(4,22,2425)}$.

However, another clinical validation study of the Fall Prevention Behavior in stroke patients showed divergences when compared to this study in relation to the evaluation of its results, since in that one, most of the indicators presented satisfactory or excellent KIC for the evaluation of the nurses who used the instrument with the definitions. This confirms the need to tailor the definitions of each indicator to certain specific scenarios in which they can be used $^{(22)}$.

Thus, the need to develop other scientific investigations aimed at clinical validation of nursing outcomes, especially the Prevention of falls in hospital environment, is reiterated, so that definitions can be refined and thus reduce the inconsistencies among the evaluating nurses ${ }^{(4)}$.

In addition, discussing prevention behaviors in hospitalized patients can guide the management of falls by nursing and help in establishing preventive and autonomous attitudes in these patients. Because it is necessary to offer interventions that develop strength and balance, favor the practice of preventive behavior and stimulate patient independence in the context of hospitalization ${ }^{(10)}$.

\section{Study limitations}

Conducting the study in a specific population may reduce the generalization of the results to other populations. In addition, another limitation is related to the fact that clinical validation was performed in a single scenario of clinical and surgical hospital practice. When initially evaluated by specialists and clinically applied in hospitalized patients, the indicators related to the characteristics of the environment and the profile of these patients may have influenced the results of this study.

Contributions to the area of nursing, health or public policy

The use of Nursing Classification Systems and their Taxonomies contributes to the construction of a foundation of knowledge inherent to the profession, besides feeding one of the important steps that constitute the Nursing Process, in order to favor the Systematization of Nursing Assistance.

Thus, the clinical validation of the Fall Prevention Behavior in the hospital environment assists the nurse and the multiprofessional team: in the decision making regarding the clinical responses of the patient, in the early evaluation of the level of risk of falls of the patient regarding their preventive behaviors in health, in the identification of the behaviors that express greater vulnerability for the occurrence of falls and the need for adjustments, in the preventive action in this sense and in the continuous measurement of the patient's reaction to educational actions for the prevention of falls.

Together with these contributions, the validation of the clinical indicators on the behavior of falls prevention in the real environment subsidizes the construction of public health policies aimed at the population, in order to minimize and identify the real health problems related to falls in hospital environment.

\section{CONCLUSIONS}

The instrument referring to the NOC result of fall prevention behavior was considered valid for the population studied, since it is composed of indicators that were able to measure the health status of patients at risk of falls. It should be noted that, as verified, most of the indicators of the NOC Fall Prevention Behavior score are sufficiently described in the taxonomy, such that the titles of the indicators, even without the definitions, were considered relevant for the evaluation of health status of the patient with risk of falls in a hospital environment. Thus, it is suggested that the definitions tested be incorporated into the classification system, possibly to favor a more accurate clinical evaluation.

Some definitions of Fall Prevention Behavior still require conceptual enhancement, while others have been analyzed as appropriate for a more concrete assessment of the risk of falls in the population studied. Thus, the validated instrument still needs to be implemented in other clinical-epidemiological contexts, in order to verify its applicability, to standardize the concepts and terms used, and, consequently, to provide a clear and uniform measurement of the indicators. The instrument was considered as an important tool for the practice of nursing, since it allows the measurement and follow-up at lower levels of abstraction in regard to the prevention of falls of hospitalized patients.

The proposition and execution of this clinical validation for Nursing Outcome Fall prevention behavior favors the development of the planning and implementation phases of nursing interventions in a targeted manner, indicating in particular preventive behavior less than ideal, how much needs to evolve, besides the most appropriate intervention for each case. Thus, the benefits of implementing the instrument in practice are emphasized, in order to avoid the development of the disease and its complications.

\section{FUNDING}

This study was funded by the National Council for Scientific and Technological Development. Process No. 486043/2011-1.

\section{REFERENCES}

1. Aued GK, Bernardino E, Peres AM, Lacerda MR, Dallaire C, Ribas EN. Clinical competences of nursing assistants: a strategy for people management. Rev Bras Enferm[Internet]. 2016[cited 2017 Mar 03];69(1):130-7. Available from: http://www.scielo.br/pdf/ reben/v69n1/en_0034-7167-reben-69-01-0142.pdf

2. Monteiro FPM, Araujo TL, Costa FBC, Leandro TA, Cavalcante TF, Lopes MVO. Clinical validation of nursing diagnosis “Willingness 
for improved infant development". Rev Bras Enferm[Internet]. 2016[cited 2017 Mar 03];69(5):802-9. Available from: http://www. scielo.br/pdf/reben/v69n5/en_0034-7167-reben-69-05-0855.pdf

3. Moorhead S, Johnson M, Maas M. Classificação dos resultados de enfermagem (NOC). 5 ed. Porto Alegre: Artmed; 2013.

4. Moreira RP, Araujo TL, Lopes MVO, Cavalcante TF, Guedes NG, Chaves ES, et al. Clinical validation of nursing outcome mobility in patients with cerebrovascular accidents. Rev Gaúcha Enferm[Internet]. 2016[cited 2017 Mar 03];37(4):e54688. Available from: http://www.scielo.br/pdf/rgenf/v37n4/en_0102-6933-rgenf-1983-144720160454688.pdf

5. Almeida MA, Seganfredo DH, Barreto LNM, Lucena AF. Validation of indicators of the nursing outcomes classification for hospitalized adults at risk of infection. Texto Contexto Enferm[Internet]. 2014[cited 2017 Mar 03];23(2):309-17. Available from: http://www. scielo.br/pdf/tce/v23n2/0104-0707-tce-23-02-00309.pdf

6. Ferreira MA. O clássico e o emergente: desafios da produção, da divulgação e da utilização do conhecimento da Enfermagem. Rev Bras Enferm [Internet]. 2013[cited 2017 Mar 03];66(spe):45-50. Available from: http://www.scielo.br/pdf/reben/v66nspe/ v66nspea06.pdf

7. Abreu DROM, Oliveira JLC, Abreu ARG, Abreu HCA. Quedas no ambiente hospitalar, qualidade e segurança do paciente: metassíntese da literatura. Gestão Saúde[Internet]. 2016[cited 2017 Mar 03];7(3):1244-55. Available from: http://periodicos.unb. br/index.php/rgs/article/view/21993

8. Brasil. Ministério da Saúde. Portaria no 529 de 01 de abril de 2013. Institui o Programa Nacional de Segurança do Paciente (PNSP). Brasília DF: Ministério da Saúde; 2013.

9. Gelbard R, Inaba K, Okoye OT, Morrell M, Saadi Z, Lam L, et al. Falls in the elderly: a modern look at an old problem. Am J Surg[Internet]. 2014[cited 2017 Mar 03];208(2):249-53. Available from: https://linkinghub.elsevier.com/retrieve/pii/S0002-9610(14)00150-0

10. Moura LA, Araújo JNM, Fernandes APNL, Araújo MG, Silva AB, Olímpio JA. Fall prevention behavior among hospitalized elderly patients. Int Arch Med[Internet]. 2016[cited 2017 Mar 03];9(57):1-9. Available from: http://imed.pub/ojs/index.php/iam/article/ view/1488/1189

11. Brasil. Ministério da Saúde. Conselho Nacional de Saúde. Resolução n. 466/12. Diretrizes e normas regulamentadoras das pesquisas que envolvem seres humanos; 2012.

12. Jekel JF, Elmore JG, Katz DL. Epidemiologia, bioestatística e medicina preventiva. Porto Alegre: Artes Médicas; 2002.

13. Vitor AF, Moura LA, Fernandes APNL, Botarelli FR, Araújo JNM, Vitorino ICC. Risk for falls in patients in the postoperative period. Cogitare Enferm[Internet]. 2015[cited 2017 Mar 03];20(1):29-37. Available from: https://revistas.ufpr.br/cogitare/article/ download/38509/24834

14. Freitas R, Santos SSC, Hammerschmidt KSA, Silva MA, Pelzer MT. Cuidado de enfermagem para prevenção de quedas em idosos: proposta para ação. Rev Bras Enferm [Internet]. 2011[cited 2017 Mar 03];64(3):478-85. Available from: http://www.scielo.br/pdf/ reben/v64n3/v64n3a11.pdf

15. Nascimento JS, Tavares DMS. Prevalence and factors associated with falls in the elderly. Texto Contexto Enferm [Internet]. 2016[cited 2017 Mar 03];25(2):e0360015. Available from: http://www.scielo.br/pdf/tce/v25n2/en_0104-0707-tce-25-02-0360015.pdf

16. Sousa JAV, Stremel AIF, Grden C RB, Borges PKO, Reche PM, Silva JHO, et al. Risk of falls and associated factors in institutionalized elderly. Rev Rene[Internet]. 2016[cited 2017 Mar 03];17(3):416-21. Available from: http://www.periodicos.ufc.br/rene/article/ viewFile/3484/2727

17. Oliveira AS, Trevizan PF, Bestetti MLT, Melo RC. Fatores ambientais e risco de quedas em idosos: revisão sistemática. Rev Bras Geriatr Gerontol[Internet]. 2014[cited 2017 Mar 03];17(3):637-45. Available from: http://www.redalyc.org/articulo.oa?id=403838839016

18. Vaccari E, Lenardt MH, Willig MH, Betiolli SE, Oliveira ES. Safety of the hospital environment in terms of preventing falls on the part of the elderly: a descriptive study. O Braz J Nurs[Internet]. 2014[cited 2017 Mar 03];13(3):271-81. Available from: https:// www.objnursing.uff.br/index.php/nursing/article/view/4753

19. Oliveira ARS, Costa AGS, Sousa VEC, Moreira RP, Araújo TL, Lopes MVO, et al. Condutas para a prevenção de quedas de pacientes com acidente vascular encefálico. Rev Enferm UERJ[Internet]. 2011[cited 2017 Mar 03];19(1):107-13. Available from: http://www. facenf.uerj.br/v19n1/v19n1a18.pdf

20. Morais HCC, Holanda GF, Oliveira ARS, Costa AGS, Ximenes CMB, Araujo TL. Identificação do diagnóstico de enfermagem "risco de quedas em idosos com acidente vascular cerebral". Rev Gaúcha Enferm[Internet]. 2012[cited 2017 Mar 03];33(2):11724. Available from: http://www.scielo.br/pdf/rgenf/v33n2/17.pdf

21. Severo IM, Almeida MA, Kuchenbecker R, Vieira DFVB, Weschenfelder ME, Pinto LRC, et al. Fatores de risco para quedas em pacientes adultos hospitalizados: revisão integrativa. Rev Esc Enferm USP [Internet]. 2014[cited 2017 Mar 03];48(3):540-54. Available from: http://www.scielo.br/pdf/reeusp/v48n3/0080-6234-reeusp-48-03-540.pdf

22. Costa AL, Araújo TL, Cavalcante TF, Lopes MVO, Kumakura ARSO, Costa FC. Clinical validation of the nursing outcome falls prevention behavior in people with stroke. Appl Nurs Res[Internet]. 2017[cited 2017 Mar 03];33:67-71. Available from: https:// linkinghub.elsevier.com/retrieve/pii/S0897-1897(16)30248-8

23. Lopes MVO, Silva VM, Araujo TL. Validação de diagnósticos de enfermagem: desafios e alternativas. Rev Bras Enferm[Internet]. 2013[cited 2017 Mar 03];66(5):649-55. Available from: http://www.scielo.br/pdf/reben/v66n5/02.pdf 
24. Silva VM, Lopes MVO, Araujo TL, Beltrão BA, Monteiro FPM, Cavalcante TF, et al. Operational definitions of outcome indicators related to ineffective breathing pattern in children with congenital heart disease. Heart Lung[Internet]. 2011 [cited 2017 Mar 03];40(3):e70-7. Available from: https://linkinghub.elsevier.com/retrieve/pii/S0147-9563(10)00469-3

25. Santos FAAS, Melo RP, Lopes MVO. Characterization of health status with regard to tissue integrity and tissue perfusion with venous ulcers according to the nursing outcomes classification. J Vasc Nurs[Internet]. 2010[cited 2017 Mar 03];28(1):14-20. Available from: https://linkinghub.elsevier.com/retrieve/pii/S1062-0303(09)00127-7 